Jurnal Hukum Mimbar Justitia

Fakultas Hukum Universitas Suryakancana

Vol. 4 No. 2 - Desember 2018, hlm. 167-185.

ISSN: 2477-5681 (Cetak), ISSN: 2580-0906 (Online)

Open Access at: https://jurnal.unsur.ac.id/jmi

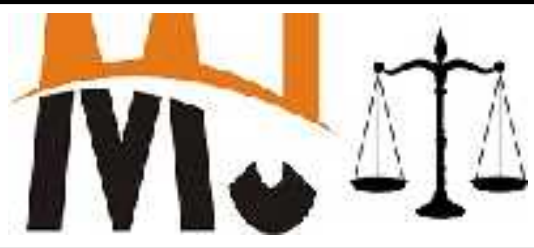

\title{
INNOVATION FUNGSI PERGURUAN TINGGI DITENGAH PUSARAN PEMILIHAN KEPALA DAERAH TAHUN 2018
}

\author{
Dedi Mulyadi \\ Universitas Suryakancana \\ Email: dedimulyadi53@gmail.com
}

Masuk: September 2018 Penerimaan: Oktober 2018 Publikasi: Desember 2018

\begin{abstract}
ABSTRAK
Fungsi Perguruan Tinggi sebagai wadah pembelajaran mahasiswa dan masyarakat, wadah pendidikan calon pemimpin bangsa, sebagai pusat pengembangan ilmu pengetahuan dan teknologi, sebagai pusat kajian kebijakan dan kekuatan moral untuk mencari dan menemukan kebenaran dan pusat pengembangan peradaban bangsa dengan demikian maka peran Perguruan Tinggi menjadi evisentrum atas kemajuan peradaban suatu bangsa. Khusus dalam kontek demokrasi lokal Pemilihan Kepala Daerah (PILKADA) Provinsi dan Kabupaten/Kota di Tahun 2018 sebagai bagian dari implementasi demokrasi lokal.

Berdasarkan hal tersebut, untuk memudahkan pembatasan dalam pembuatan makalah ini maka ditentukan identifikasi masalah terdiri dari: Bagaimana Peran Perguruan Tinggi dalam Pelaksanaan Pilkada Tahun 2018 ?, Bagimana permasalahan pelaksanaan peran Perguruan Tinggi dalam Pilkada Tahun 2018 ? melalui metode yuridis normatif. Dengan demikian maka Perguruan Tinggi harus dapat mengambil bagian dalam memperbaiki problem regulasi, sistem penyelenggaraan dan kulaitas sumber daya manusia yang dibutuhkan dalam sebuah kontestasi politik lokal atau PILKADA khusus Pilkada Tahun 2018 ini.
\end{abstract}

Kata Kunci: Demokrasi; Demokrasi Lokal; Pemilu Kepala Daerah; Kontestasi Politik

\section{ABSTRACT}

The function of higher education as a learning forum for students and the community, a forum for the education of prospective leaders of the nation, as a center for the development of science and technology, as a center for policy studies and moral power tp find and discover national development centers. Progress of a nation's civilization. Specifically in the context of local democracy in the election of regional heads (PILKADA) of provinces/cities in 2018 as part of the implementation of local democracy.

Based on this, to facilitate the limitation in making this paper, the identification of the problem consists of: How is the role of higher education in the implementation of the 2018 election? Thus the tertiary institution must be able to take part in correcting the problem of regulation, the system of administration and the quality of human resource 
needed in a local political contest or the Regional Election Committe, especially the 2018 regional election.

Keywords: Democracy; Local Democracy; Regional Head Elections; Political Contestation.

\section{PENDAHULUAN}

Undang-undang Nomor 12 tahun 2014 Tentang Pendidikan Tinggi mengartikan Pendidikan Tinggi sebagai jenjang pendidikan setelah pendidikan menengah yang mencakup program diploma, program sarjana, program megister, program doktor, dan program profesi, serta program spesialis, yang diselenggarakan oleh perguruan tinggi berdasarakan kebudayaan bangsa Indonesia.

Sesuai Pasal 4 undang-undang tersebut, grand desain fungsi Perguruan Tinggi untuk mengembangkan kemampuan dan membentuk watak serta peradaban bangsa yang bermartabat dalam rangka mencerdaskan kehidupan bangsa, mengembangkan Sivitas Akademika yang inovatif, responsif, kreatif, terampil, berdaya saing, dan koopratif melalui pelaksanaan Tridharma Perguruan Tinggi dan pengembangan ilmu pengetahuan dan teknologi dengan memperhatikan dan menerapkan nilai humaniora.
Pasal tersebut di atas, kemudian dipertegas oleh Pasal 58 Ayat (1) yang menyatakan Perguruan Tinggi melaksanakan fungsi dan peran sebagai wadah pembelajaran mahasiswa dan masyarakat dengan demikian harus terjalin hubungan yang saling membutuhkan antara mahasiswa dan masyarakat dalam proses pembelajaran, wadah pendidikan calon pemimpin bangsa, maka segala upaya yang dilaksanakan oleh Perguruan Tinggi harus berorientasi pada penciptaan pemimpin bangsa kedepan.

Perguruan Tinggi sebagai pusat pengembangan ilmu pengetahuan dan teknologi, sebagai pusat kajian kebijakan dan kekuatan moral untuk mencari dan menemukan kebenaran dan pusat pengembangan peradaban bangsa dengan demikian maka peran Perguruan Tinggi menjadi evisentrum atas kemajuan peradaban suatu bangsa. Khusus dalam kontek demokrasi Pemilihan Kepala Daerah (PILKADA) Provinsi dan Kabupaten/Kota di Tahun 2018 sebagai bagian dari implementasi 
Dedi Mulyadi

Jurnal Hukum Mimbar Justitia

Vol. 4 No. 2 - Desember 2018

demokrasi lokal. Pengertian demokrasi menurut Abraham Lincoln, adalah "pemerintahan dari rakyat, oleh rakyat, dan untuk rakyat". yang mengandung makna kekuasaan ada di tangan rakyat,

M. Duverger dalam 'les Regimes Politiques' memberi arti demokrasi sebagai cara pemerintahan di mana golongan yang memerintah dan peradaban suatu bangsa. Khusus dalam kontek demokrasi Pemilihan Kepala Daerah (PILKADA) Provinsi dan Kabupaten/Kota di Tahun 2018 sebagai bagian dari implementasi demokrasi lokal.

Pengertian demokrasi menurut Abraham Lincoln, adalah "pemerintahan dari rakyat, oleh rakyat, dan untuk rakyat". yang mengandung makna kekuasaan ada di tangan rakyat, M. Duverger dalam 'les Regimes Politiques' memberi arti demokrasi sebagai cara pemerintahan di mana golongan yang memerintah dan golongan yang diperintah sama dan tidak terpisah-pisah. ${ }^{1}$ Salah satu syarat pokok negara demokrasi adalah dalam negara tersebut adanya sistem pemilihan

1 Miriam Budiarjdo, 1997, Dasar-Dasar Ilmu Politik, Cet. XIII, Gramedia Pustaka Utama, Jakarta, hlm. 54 umum (pemilu) yang jujur dan adil (free and fair elections).

Negara Indonesia sebagai negara hukum yang demokratis merupakan pengejewantahan dari nilai-nilai demokrasi dalam politik hukum bangsa Indonesia sekarang dan kedepan, hal ini sejalan dengan substansi UndangUndang Dasar 1945 Pasal 1 ayat (2) yang menyatakan "Kedaulatan berada di tangan rakyat dan dilaksanakan menurut Undang-Undang Dasar".

Implementasi Ayat (2) tersebut, khusus dalam pengisian jabatan politik di daerah dilaksanakan melalui model pemilihan Kepala Daerah/Wakil Kepala

Daerah secara langsung, konstitusi UUD 1945 hasil amandemen, Pasal 18 ayat (4) menyatakan bahwa 'Gubernur Bupati, dan Walikota masing-masing sebagai kepala pemerintah daerah provinsi, kabupaten, dan kota dipilih secara demokratis'.

Prasa '....dipilih secara demokratis' tersebut kemudian di terjemahkan melalui Undang-Undang No. 1 Tahun 2015 Tentang Penetapan Peraturan Pengganti Undang-Undang No. 1 Tahun 2014 Tentang Pemilihan Gubernur, Bupati, dan Walikota menjadi Undang-Undang. Yang telah 
Dedi Mulyadi

Jurnal Hukum Mimbar Justitia

Vol. 4 No. 2 - Desember 2018

beberapa kali diubah, terakhir dengan Undang-Undang Nomor 10 Tahun 2016. Dalam implementasinya dinamika pilkada serentak Tahun 2018 di Indonesia banyak memunculkan berbagai potensi permasalahan yang memerlukan keterlibatan banyak pihak khususnya pemikiran dari kalangan akademisi atau pihak Perguruan Tinggi.

Fungsi Perguruan Tinggi sesuai Pasal 14 Undang-Undang Nomor 16 Tahun 2014 dalam implementasinya memerlukan pemaknaan proporsional dimana Tri Dharma Perguruan Tinggi menjadi basis keterlibatan dalam pesta demokrasi daerah melalui Pemilihan Kepala Daerah (PILKADA) khususnya Tahun 2018 ini.

Keterlibatan Perguruan Tinggi dalam dinamika demokrasi lokal (PILKADA) tersebut, tidak saja mendapat respon posistif tetapi juga seringkali mendapat respon sebaliknya (negatif) baik di dalam Perguruan Tinggi sendiri maupun diluar Perguruan Tinggi.

Di dalam Perguruan Tinggi tersebut, berkembang pendapat menjadi dua kubu besar, kubu pertama pendapat yang pro tentang pentingnya peran dan fungsi Perguruan Tinggi dalam proses peningkatan kualitas demokrasi khususnya dalam PILKADA, dan kubu yang kedua berpendapat bahwa Perguruan Tinggi tidak boleh berpolitik praktis, artinya Perguruan Tinggi harus steril dari berbagai kepentingan politik khususnya dalam dinamika demokrasi lokal (PILKADA).

Penulis hanya akan membahas mengenai pendapat kubu yang pertama (kubu yang pro) dalam kontek demokerasi lokal PILKADA Internalisasi nilai inovasi dalam kebijakan Perguruan Tinggi sesuai Pasal 58 dapat dilaksanakan dengan berbagai upaya dan kebijakan internal dan mendorong kebijakan ekternal (eksekutif maupun legislatif).

Gambaran ini lah yang ingin diexplor dalam pembahasan selanjutnya melalui makalah dengan judul 'INNOVATION FUNGSI

PERGURUAN TINGGI DITENGAH PUSARAN PEMILIHAN KEPALA DAERAH TAHUN 2018' dari latar belakang di atas, kami sampaikan identifikasi terdiri dari bagaimana Peran Perguruan Tinggi dalam Pelaksanaan Pilkada Tahun 2018 ? Bagaimana permasalahan pelaksanaan peran 
Dedi Mulyadi

Jurnal Hukum Mimbar Justitia

Vol. 4 No. 2 - Desember 2018

Peguruanan Tinggi dalam Pilkada

Tahun 2018 ?

Berdasarkan permasalahan di atas, penulis melaksanakan penelitian hukum normatif sehingga yang dipergunakan adalah data sekunder, yaitu data yang berasal dari bahan pustaka. $^{2}$ Adapun metode pengumpulan datanya adalah melalui studi kepustakaan yaitu meneliti dan menggali bahan-bahan hukum atau data-data tertulis berupa kitab-kitab perundang-undangan,

putusan pengadilan, buku-buku, jurnal ilmiah, majalah, surat kabar, web dan bahan hukum lainya yang berkaitan dengan permasalahan yang akan diteliti, jadi penelitian ini dipahami sebagai penelitian kepustakaan, yaitu penelitian terhadap bahan sekunder. ${ }^{3}$

II. PEMBAHASAN

\section{A. Peran Perguruan Tinggi Dalam Pelaksanaan Pilkada Tahun 2018}

Pemilihan umum (pemilu) di Indonesia merupakan salah satu sarana

2 Soerjono Soekanto, 2008, Pengantar Penelitian Hukum, UI Press, Jakarta, hlm. 11.

3 Soerjono Soekanto, 1985, Penelitian Hukum Normatif suatu tinjuan singkat, Raja Grafindo, Jakarta, hlm. 15. demokrasi. $^{4} \quad$ Pesta demokrasi yang merupakan perwujudan tatanan kehidupan bernegara yang berkedaulatan rakyat, pemerintahan dari dan untuk rakyat. ${ }^{5}$ Pelaksanaan Pemilu dapat berdimensi tiga capaian diantaranya :

a. Lewat pemilu kita dapat menguji hak - hak politik rakyat secara masif dan serempak;

b. Melalui pemilu kita dapat berharap terjadinya proses rekrutmen politik secara adil, terbuka, dan kompetitif;

4 Wahyu Nugroho, Politik Hukum Pasca Putusan Mahkamah Konstitusi atas Pelaksanaan Pemilu dan Pemilukada di Indonesia, dalam Jurnal Konstitusi, Vol. 13, No.3, September 2016, Jakarta, Mahkamah Konstitusi, hlm. 482; Demokrasi di Negara manapun di dunia ini, biasa akan mengikuti 4 (empat) scenario evolusi yakni membaik, stagnan, menurun atau gagal. Kita semua tentu sangat menginginkan bahwa keberhasilan demokrasi harus kita bangun, dengan segala daya dan upaya dalam setiap langkah oleh segenap elemen bangsa ini. Pemilihan umum ditingkat nasional atau daerah hanya sebuah tools dan sarana daeri demokrasi itu sendiri. Membangun demokrasi memang tidak cukup pemilu satu, banyak aspek dan elemen lain yang harus ikut membangun demokrasi.

5 Satrya Pangadaran Marpaung, Strategi Hukum dan Demokrasi di Indonesia dalam Pelaksanaan Otonomi Daerah, dalam Law Review, Vol. XII, No. 3, Maret 2013, Jakarta, Fakultas Hukum Universitas Pelita Harapan, hlm. 381; Pemilihan langsung kepala daerah melalui konsep otonomi daerah memang merupakan suatu terobosan yang baik bagi Indonesia dalam berdemokrasi. 
Dedi Mulyadi

Jurnal Hukum Mimbar Justitia

Vol. 4 No. 2 - Desember 2018

c. Melalui pemilu kita dapat menginginkan adanya pola pergiliran kekuasaan yang damai.

Dengan demikian maka Pemilu ini merupakan bagian yang tak terpisahkan dari sebuah sistem demokrasi yang sedang berkembang di Indonesia pada saat ini khususnya mengani pelaksanaan demokrasi lokal.

Babak baru dalam penyelenggaraan demokrasi lokal di Indonesia sejak bulan Juni Tahun 2005. Kepala Daerah (gubernur, bupati, dan walikota) yang sebelumnya dipilih melalui mekanisme pemilihan oleh DPRD sesuai UU No. 5 Tahun 1974, UU No. 22 Tahun 1999 Tentang Pemerintahan Daerah yang hasilnya dianggap tidak mencerminkan nilainilai demokrasi bahkan kecenderungan politik dagang sapi (bargaining) yang mengakibatkan ketidak percayaan dari masyarakat terhadap hasil dari proses demokrasi perwakilan tersebut.

Berdasarkan kondisi tersebut, sejak bulan Juni 2005 maka pemilihan kepala daerah dilaksanakan melalui mekanisme dipilih secara langsung oleh rakyat melalui proses pemilihan kepala daerah langsung (Pilkada), sesuai UU No. 32 Tahun 2014 Tentang
Pemerintahan Daerah, selanjutnya mulai tahun 2015 sesuai dengan UU No. 8 Tahun 2015 dilaksanakan Pilkada serentak Tahap ke I dan Tahun 2017 telah dilaksanakan Pilkada Serentak Tahap II dan Pilkada serentak Tahun 2018.

Makna terpenting dari Pilkada tersebut adalah 1) merupakan pengakuan konstitusional atas hak rakyat sebagai pemegang kedaulatan rakyat; 2) pelembagaan politik peran substansial rakyat sebagai subjek hukum; 3) diharapkan terciptanya keseimbangan politik makro dan mikro dalam kehidupan ketatanegaraan kita, khususnya antara eksekutif dan legislatif. $^{6}$

Secara historis latar belakang pilihan politik terhadap sistem Pilkada secara langsung merupakan koreksi atas pelaksanaan pilkada terdahulu. Implementasi sistem Pilkada langsung menunjukkan perkembangan penataan sistem demokrasi daerah dalam kerangka transisi liberalisasi politik. Tentu saja, dipilihnya sistem pilkada

\footnotetext{
6 Andi Saputa, Faktor-faktor Kemenangan Calon Incumbent dalam Pilkada, dalam Jurnal Konstitusi, PK2P Universitas Muhammadiyah Yogyakarta, Vol. III, No. 1, Juni 2010, Jakarta, Mahkamah Konstitusi, hlm. 95.
} 
langsung secara serentak memberikan berbagai ekspektasi demokrasi lokal yang baru.

Dalam perkembangan global, ${ }^{7}$ maka latar belakang pemilihan kepala daerah langsung dalam perkembangan demokrasi lokal di Indonesia, diantaranya :

a. Pilkada langsung sebagai jawaban atas desakan dunia internasional akan pelaksanaan demokrasi di Indonesia, khususnya demokrasi lokal;

b. Pilkada langsung sebagai jawaban atas aspirasi dan ekspektasi rakyat mengingat pemilihan presiden, DPR, DPD bahkan Kepala Desa selama ini dilaksanakan secara langsung;

c. Pilkada langsung merupakan perkembangan demokrasi lokal yang konstitusional sesuai dengan amanat UUD 1945 Pasal 18 Ayat (4), Gubernur, Bupati dan Wali

7 Mudiarti Trisnaningsih, Peranan Hukum di Era Globalisasi, dalam Jurnal Ilmiah Hukum Litigasi, Vol. 1, No. 1, April 2012, Bandung, Fakultas Hukum Universitas Pasundan Bandung, hlm. 1347; secara konseptual Theodore Levitte sering disebut-sebut sebagai orang yang pertama kali menggunakan istilah globalisasi pada tahun 1985, globalisasi juga dapat disebut internasionalisasi, liberalisasi, westernisasi, transplanetari dan supra teritorialitas.
Kota, masing-masing sebagai kepala pemerintahan daerah provinsi, kabupaten, dan kota dipilih secara demokratis, selanjutnya di interpretasikan melalui Undang-Undang No. 10 Tahun 2016 Perubahan Kedua atas Undang-Undang No. 1 Tahun 2015 Tentang Penetapan Peraturan Pengganti UndangUndang No. 1 Tahun 2014 Tentang Pemilihan Gubernur, Bupati, dan Walikota menjadi Undang-Undang;

d. Pilkada langsung sebagai sarana pembelajaran demokrasi lokal (civic education), ia sebagai sarana pembelajaran demokrasi bagi rakyat, yang sebelumnya demokrasi hanya bersifat elitis;

e. Pilkada langsung sebagai sarana dalam memperkuat otonomi daerah dengan moto 'permasalahan daerah, diselesaikan di daerah dengan cara daerah, oleh masyarakat daerah';

f. Pilkada langsung sebagai sarana strategis dalam proses kaderisasi kepemimpinan nasional, salah satu produk dalam wujud 
Dedi Mulyadi

Jurnal Hukum Mimbar Justitia

Vol. 4 No. 2 - Desember 2018

kaderisasi pilkada adalah Presiden

Joko Widodo.

Dengan demikian Pilkada langsung dinilai sebagai perwujudan pengembalian hak-hak dasar masyarakat di daerah dengan memberikan kewenangan yang utuh dalam rangka rekrutmen pimpinan daerah melalui legitimasi demokrasi lokal sebagai tujuan Pilkada. $^{8}$ Keberhasilan pilkada untuk melahirkan kepemimpinan daerah yang demokratis dan legitimasi, sesuai kehendak dan tuntutan rakyat banyak, hal ini sangat tergantung pada artikulasi demokrasi lokal masyarakat sendiri dalam menginterpretasi perkembangan dan dinamika ekspektasi demokrasi tersebut.

Peran Perguruan Tinggi sesuai dengan Undang-Undang Nomor 12 tahun 2014 Tentang Pendidikan Tinggi, Pasal 4 Ayat (1) ....mencerdaskan kehidupan bangsa dalam kontek demokrasi diatas, melalui berbagai kebijakan yang dapat diambil oleh Perguruan Tinggi khususnya yang

\footnotetext{
Septi Nur Wijayanti, Pergeseran Kewenangan Penyelesaian Sengketa Pemilukada dari Mahkamah Agung ke Mahkamah Konstitusi, dalam Jurnal Konstitusi, Vol. III, No. 1, Juni 2010, Jakarta, Mahkamah Konstitusi, Op Cit, hlm. 94.
}

berkaitan dengan Tri Dharma Perguruan Tinggi diataranya :

1. Memperbanyak Penelitian/Study dan Diskusi tentang Pilkada. Pilkada merupakan perwujudan demokrasi lokal yang sedang menggejala di Indonesia saat ini maka dengan demikian dibutuhakan berbagai penelitian/study tentang efektivitas pelaksanaan Pilkada mengingat berbagai permasalahan Pilkada dari mulai : Money politik, dengan memanfaatkan keterbatasan ekonomi masyarakat pada umumnya maka money politik menjadi salah satu upaya yang paling cepat memburu suara masyarakat; Maraknya Informasi Hoak, sebagai bagian dari exses perkembangan era ekonomi digital yang dapat menyulut terjadinya disintegrasi bangsa; Intimidasi, intimidasi ini sering dilakukan kepada para pemilih terutama di daerah-daerah ex konplik seperti Aceh dll; Kampanye negatif, dilakukan karena masyarakat tidak mendapatkan informasi yang cukup tentang calon sehingga 
Dedi Mulyadi

Jurnal Hukum Mimbar Justitia

Vol. 4 No. 2 - Desember 2018

dimanfaatkan oleh kelompok lawan dengan informasi yang negatif baik di media sosial, media cetak dan media elektronik; Borong partai demi calon tunggal, perkembangan terakhir sesuai dengan putusan Mahkamah Konstitusi (MK) yang membolehkan calon tunggal dalam pelaksanaan Pilkada langsung memberikan ruang bagi calon dengan kekuatan kapital besar untuk memborong partai politik peserta pemilu, sehingga calon lain tidak kebagian partai pengusung sedangkan calon independen sangat sulit. Permasalahan Sara (suku, ras dan agama), penomena permasalahan sara sebagai bagian dari permasalahan Pilkada Langsung serentak ini, dapat kita lihat dalam pemilihan Gubernur DKI Jakarta, dimana calon No. 2 (Ahok dan Jarot) di perkarakan dengan delik penodaan agama yang sampai sekarang masih berlanjut;

Berbagai permasalahan diatas, membutuhkan peran aktif dari Perguruan Tinggi untuk membuat berbagai stady, diskusi dan penelitian sebagai pertimbangan agar ketika pemerintah mengambil kebijakan guna menyelesaiakan permasalahan diatas jelas basis data dan teorinya. Sehingga kebijakan tersebut dihapakan tidak salah sasaran dan dapat menjadi solusi atas berbagai permasalahan tersebut.

2. Membuat Pusat Studi Pilkada;

Pusat Studi Pilkada pada hakekatnya adalah sebagai wadah yang tidak hanya menampung berbagai kegiatan penelitian dan pengkajian dosen, dosen dan mahasiswa, dari berbagai perespektif bidang ilmu, program studi, dan fakultas dilingkungan Universitas atau Sekolah Tinggi khusus mengenai Pemilihan Kepala Daerah (Pilkada) dari berbagai perespektif.

Proses pendirian Pusat Studi dapat didirikan di tingkat Universitas mengingat lintas keilmuan sesuai dengan tahapan usulan pembuatan pusat studi yang tertuang dalam sebuah proposal yang mampu menggambarkan latar belakang, bidang kajian, tujuan, milestone, 
Dedi Mulyadi

Jurnal Hukum Mimbar Justitia

Vol. 4 No. 2 - Desember 2018

dan program kerja; diusulkan oleh para peneliti dari berbagai lintas keilmuan, rencana penelitian tahunan, rencana publikasi, rencana penyelenggara even ilmiah, rencana pengembangan kerjasama, dan rencana pembiayaan.

Proses pendirian Pusat Studi Pemilihan Umum tersebut menggambarkan strategisnya peran Perguruan Tinggi dalam meningkatakan kualitas pelaksanaan demokrasi lokal melalui sebuah penelitian yang dilakukan oleh Pusat Studi Pemilu, hasil studi tersebut dapat menjadi suplemen bagi pemerintah dalam menentukan kebijakan strategis selanjutnya.

Inilah gambaran bagaimana Pusat Studi menjadi strategis untuk menjadi pilihan kebijakan di tingkat Universitas dalam medorong agar kebijakan pemilu yang di buat oleh pemerintah selalu berdasarkan kepada hasil studi yang dilakukan oleh sebuah lembaga Pusat Studi.

3. Kebijakan Perguruan Tinggi mengenai pembukaan jurusan
Pemilu di Fakultas Hukum konsentrasi jurusan Hukum Pemilu dan Fakultas Ilmu Sosial dan Ilmu Politik konsentrasi Jurusan Kepemiluan.

Sesuai Undang-Undang Nomor 12 tahun 2014 Tentang Pendidikan Tinggi, Pasal 4 yang kemudian dipertegas oleh Pasal 58 Ayat (1) merupakan standar baku dalam pelaksanaan fungsi Perguruan Tinggi guna menyediakan kebutuhan akan kualitas sumber daya manusia (SDM) yang mempunyai pemahaman cukup tentang pemilu.

Kebijakan Perguruan Tinggi tersebut secara konkrit malalui pembukaan konsentrasi ilmu kepemiluan dalam prodi ilmu hukum ataupun prodi ilmu sosial dan ilmu politik menjadi alternatif jawaban akan kebutuhan insprastruktur penyelenggara pemilu yang handal dan profesional.

Melalui kebijakan tersebut, maka kedepan dihapkan tidak ada lagi insprastruktur pemilu (KPU, PANWAS, Polisi, Jaksa, Pengacara, dan Pengadilan 
Dedi Mulyadi

Jurnal Hukum Mimbar Justitia

Vol. 4 No. 2 - Desember 2018

Pemilu) yang bersifat ad-hoc mengingat sumber daya yang dibutuhkan sudah melalui proses pendidikan yang terpola sesuai standar Perguruan Tinggi baik di fakultas hukum maupun di fakultas sosial dan ilmu politik

4. Kebijakan ekternal mendorong agar institusi penyelenggara pemilu tidak bersifat ad-hoc tetapi bersifat permanen dan lahirnya undang-undang pemilu sebagai undang-undang payung (lex generalis) yang menaungi undang-undang Penyelenggara Pemilu, Pilkada, Pileg dan Pilprers (lex specialis).

Perguruan Tinggi dapat mendesakan alternatif solusi dari permasalahan infrastruktur Pemilu yang berkembang sekarang (Pemilu Legislatif, Pemilu Presiden dan Pemilu Kepala Daerah) dianataranya karena infrastruktur Pemilu yang bersifat ad-hoc misalnya Polisi, Jaksa, Pengacara dan Hakim. Pendidikan yang di lakukan oleh institusi tersebut hanya berupa diklat selama 1 (satu) minggu, pertanyaanya bagaimana standar keilmuan yang dapat diharapkan melalui pelatihan dalam 1 minggu tersebut, padahal permasalahan pemilu sangat tidak mudah dan sangat komplek. maka Penulis berpendapat salah satu solusinya kedepan berbagai infrastruktur pemilu tersebut harus bersifat permanen.

Adapun infrastruktur tersebut harus diisi oleh sumber daya manusia yang mempunyai kompetensi terhadap penyelenggaraan pemilu dari berbagai prespektif sesuai dengan kebutuhan masing-masing diantaranya KPU, PANWAS, Polisi, Jaksa, Pengacara, dan Pengadilan Pemilu (Hakim Pemilu). ${ }^{9}$

Dengan demikian maka diharapkan para pemangku kebijakan tersebut dapat merencanakan berbagai kebijakan (Legislasi, Aplikasi, Yudikasi dan Evaluasi) secara berkelanjutan untuk melaksanakan Pemilu yang Luber, Jurdil, Profesional, Proporsional dan akuntabel. 
Untuk mengisi berbagai jabatan tersebut, khusus dalam institusi pelaksana pemilu maka dibutuhkan sumber daya manusia yang dapat melaksanakan berbagai tugas dan fungsi jabatan yang berhubungan dengan penyelenggaraan Pemilu. Dengan demikian maka institusi pemilu yang harus diisi oleh petugas yang mempunyai kompetensi khusus pemilu sesuai dengan regulasi tersebut di atas, terdiri dari : KPU, Panwas, DKPP, Polisi, Jaksa, Pengacara dan Hakim di Pengadilan Pemilu yang harus mempunyai pemahaman komperhensif tentang Pemilu.

Berkaitan dengan regulasi yang dibutuhkan agar sejalan dengan pembenahan institusi ad-hoc ke instiusi permanen maka dibutuhkan regulasi pilkada yang bersifat umum (lex generalis) disamping undang-undang yang bersifat khusus (lex specialis) yang sudah ada sekarang. Regulasi sebagai produk yang dihasilkan lembaga legislatif sesuai dengan Undang-Undang
Nomor 11 Tahun 2012 tentang Hirearki Perundang-Undangan. Regulasi tersebut harus mencerminkan hukum yang hidup (living law), bukan hanya aturan yang ada dalam kitab undangundang (law books).

Sistematika hukum yang menjadi regulasi pilkada pada saat ini, terdiri dari UUD 1945, Pasal 18 Ayat (4) sebagai landasan konstitusionalnya dan landasan operasionalnya secara khusus (lex specialis) diatur oleh UndangUndang No. 10 Tahun 2016 Perubahan Kedua atas UndangUndang No. 1 Tahun 2015 Tentang Penetapan Peraturan Pengganti Undang-Undang No. 1 Tahun 2014 Tentang Pemilihan Gubernur, Bupati, dan Walikota menjadi Undang-Undang, UU No. 15 Tahun 2011 Tentang Penyelenggara Pemilihan Umum yang ditjemahkan oleh Peraturan KPU, Peraturan Bawaslu, Peraturan MK dan sebaginya.

Kedepan dibutuhkan aturan yang dapat meng-integrasikan berbagai aturan yang bersifat khusus tersebut, ke dalam sebuah regulasi 


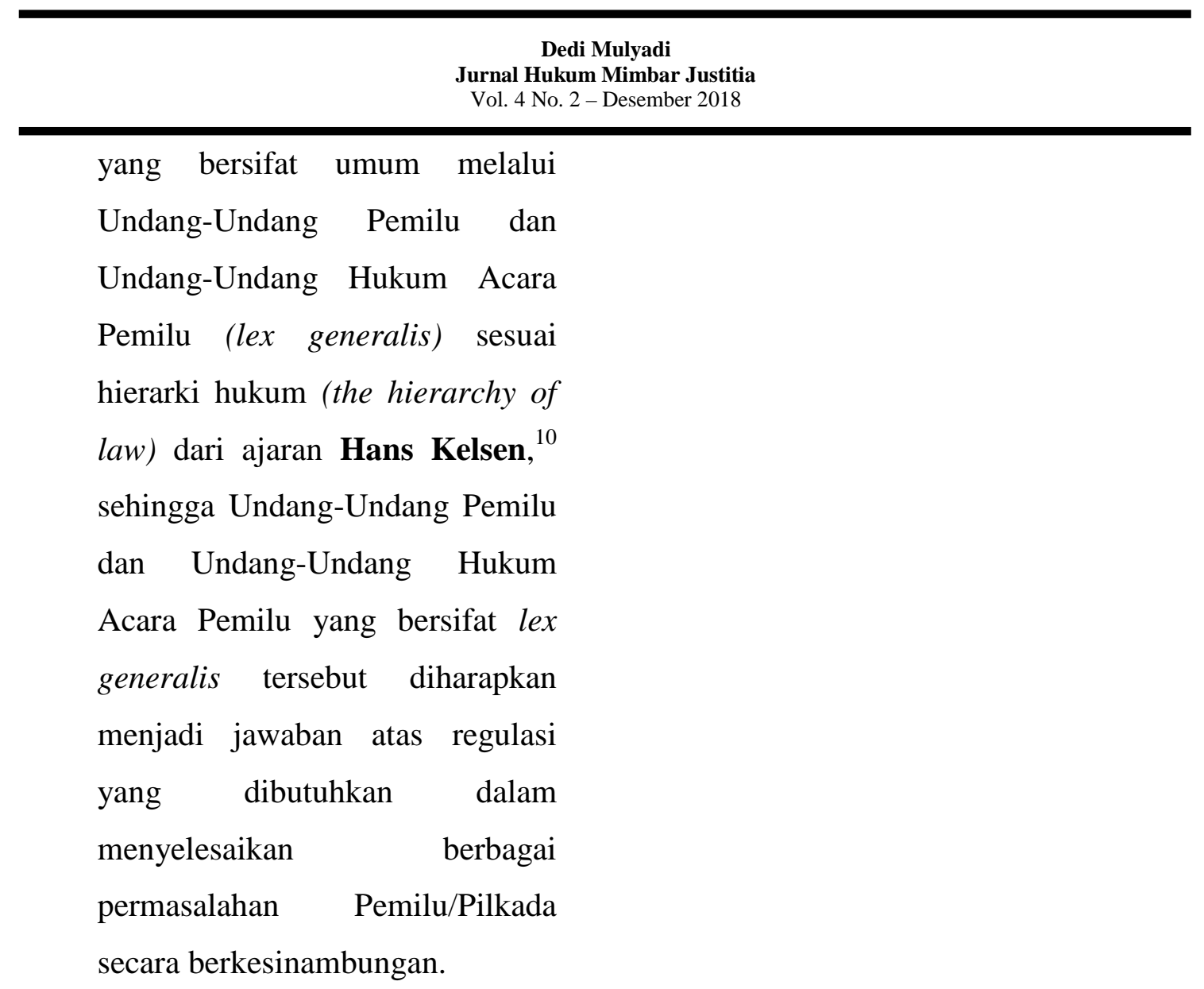

Sistematika regulasi Pemilihan

Umum yang diharapkan dapat menjadi solusi dari perespektif penyelenggaraan pemilu agar memenuhi asas LUBER JURDIL Propesional, Proporsional dan akuntabel lebih baik lagi kedepan sesuai bagan dibawah ini :

10 Iskandar Muda \& Muhammad Kadafi, Penerapan Konsep Hukum Pembangunan Ekonomi dalam upaya pencegahan eksploitasi pekerja alih daya, Kajian Putusan Mahkamah Konstitusi Nomor 27/PPU-IX/2011, dalam Jurnal Yudisial, Vol. 6 No. 1 April 2013, Jakarta, Komisi Yudisial, hlm. 18; yang berintikan bahwa norma hukum merupakan suatu susunan berjenjang dan setiap norma hukum yang lebih rendah bersumber dari kaidah yang lebih tinggi. 
Jurnal Hukum Mimbar Justitia

Fakultas Hukum Universitas Suryakancana

Vol. 4 No. 2 - Desember 2018, hlm. 167-185.

ISSN: 2477-5681 (Cetak), ISSN: 2580-0906 (Online)

Open Access at: https://jurnal.unsur.ac.id/jmj

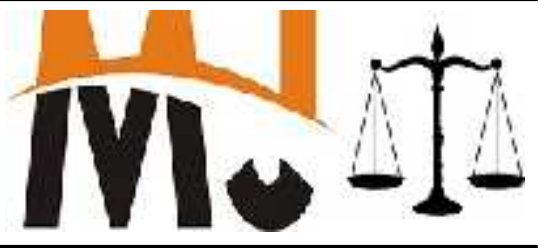

\begin{tabular}{|c|l|l|}
\hline No & \multicolumn{1}{|c|}{ Lex-Generalis } & \multicolumn{1}{|c|}{ Lex-Spesialis } \\
\hline \hline 1 & Undang-Undang Dasar Tahun 1945 & \\
\hline 2 & Undang-Undang Pemilu & $\begin{array}{l}\text { Undang-Undang Penyelenggara } \\
\text { Pemilu } \\
3\end{array}$ \\
\hline 4 & & $\begin{array}{l}\text { Pemilu } \\
\text { Legislatif }\end{array}$ \\
\hline 5 & & $\begin{array}{l}\text { Undang-Undang } \\
\text { Presiden }\end{array}$ \\
\hline 6 & & Pemilu \\
\hline 7 & & \\
\hline
\end{tabular}

Bagan di atas, menggambarkan bahwa dalam pelaksanaan Pilkada kedepan dibutuhkan undang-undang payung sebagai pelaksana delegasi dari UUD 1945 yang bersifat lex-generalis atau undang-undang payung (undangundang pemilu dan undang-undang hukum acara pemilu) yang dapat menaungi undang-undang penyelenggara pemilu, pemilu presiden, pemilu legislatif dan pemilu kepala daerah. Dengan demikian maka regulasi pemilu kedepan diharpkan dapat tertata dengan baik pembagian lex generalis (formil dan materi) dan lex spesialis menjadi lebih jelas.

Peran Perguruan Tinggi yang dapat diambil adalah dengan membuat kebijakan untuk membantu mensosialisasikan dan merasionalisasikan pentingnya berbagai regulasi tersebut melalu berbagai forum ilmiah yang digagas oleh Perguruan Tinggi serta membantu mempersiapakan berbagai naskah 
Dedi Mulyadi

Jurnal Hukum Mimbar Justitia

Vol. 4 No. 2 - Desember 2018

akademik yang di butuhkan oleh regulasi tersebut.

\section{B. Permasalahan Pelaksanaan Peran Perguruan Tinggi Dalam Pilkada Tahun 2018.}

Undang-Undang Nomor 12 tahun 2014 Tentang Pendidikan Tinggi mengartikan Pendidikan Tinggi, sesuai Pasal 4 menegaskan bahwa Pendidikan Tinggi untuk membentuk watak serta peradaban bangsa yang bermartabat dalam rangka mencerdaskan kehidupan bangsa, mengembangkan Sivitas Akademika yang inovatif, responsif, kreatif, terampil, berdaya saing, dan koopratif melalui pelaksanaan Tridharma Perguruan Tinggi dan pengembangan ilmu pengetahuan dan teknologi dengan memperhatikan dan menerapkan nilai humaniora.

Selanjutnya Pasal 58 Ayat (1) yang menyatakan' Perguruan Tinggi melaksanakan fungsi dan peran sebagai wadah pembelajaran mahasiswa dan masyarakat dengan demikian harus terjalin hubungan yang saling membutuhkan antara mahasiswa dan masyarakat dalam proses pembelajaran, wadah pendidikan calon pemimpin bangsa, maka segala upaya yang dilaksanakan oleh Perguruan Tinggi harus berorientasi pada penciptaan pemimpin bangsa kedepan.

Perguruan Tinggi sebagai pusat pengembangan ilmu pengetahuan dan teknologi, sebagai pusat kajian kebijakan dan kekuatan moral untuk mencari dan menemukan kebenaran dan pusat pengembangan peradaban bangsa. Dalam pelaksanaan fungsi tersebut diatas, tenyata tidak mudah mengingat ada berbagai permasalahan yang harus dihadapi oleh Perguruan Tinggi yang secara umum permasalahan tersebut dapat dibagi menjadi dua diatarannya : permasalahan internal Perguruan Tinggi dan masalah external Perguruan Tinggi.

1. Permasalahan Internal Perguruan Tinggi, diantaranya :

a Tidak ada kesamaan pandang tentang optimalisasi fungsi Perguruan Tinggi dalam politik peraktis ada pendapat yang membolehkan kampus masuk kewilayah politik praktis dari prespektif akademisnya atau pemebelajarannya, artinya politik prakstis sebagai 
Dedi Mulyadi

Jurnal Hukum Mimbar Justitia

Vol. 4 No. 2 - Desember 2018

media pembelajaran bagi

calon intelektual dikampus.

Pendapat yang kedua adalah

pendapat yang menganggap

kampus tidak boleh

melaksanakan politik praktis

mengingat kampus harus

steril dari berbagai

kepentingan politik dan

hanya mempelajari hal-hal

yang bersifat akademik saja;

b. Secara umum berbagai hasil

penelitian yang dilakukan

oleh Perguruan Tinggi di

Indonesia mempunyai

permasalahan yang sama,

yaitu tidak dapat diakses

oleh pengguna (teknokrat

demokrasi) berkenaan

dengan berbagai penelitian

mengenai topik-topik

demokrasi dan politik

mutahir, dengan demikian

maka maksud dilakukannya

penelitian agar tercipta

sistem demokrasi yang baik

hasil penelitian tersebut

tidak dapat termanfaatkan

oleh para tekhnokrat politik.

c. Permasalahan selanjutnya

adalah permasalahan pembiayaan berbagai

kebijakan penelitian tentang

Pemilu yang dilaksanakan

oleh Perguruan Tinggi

mengingat alokasi anggaran

biaya untuk penelitian di

internal Perguruan Tinggi

sangat terbatas dan

pemenfaatan akses untuk

pembiayaan penelitian dari

negara aga sulit karena

terkendala oleh birokrasi

negara yang panjang.

2. Permasalahan Ekternal Perguruan Tinggi, diantaranya :

a. Permasalahan trash atau

kepercayaan dari

stakeholder atas

pemanfaatan hasil penelitian

yang telah dilakukan oleh

Perguruan Tinggi khsusnya

penelitian yang berkaitan

dengan Demokrasi dan

Kepemiluan.

b. Permasalahan akses

terhadap perusahaan atau

program riset pemerintah

yang menyediakan

pembiayaan penelitian

khusnya penelitian

demokrasi dan kepemiluan; 


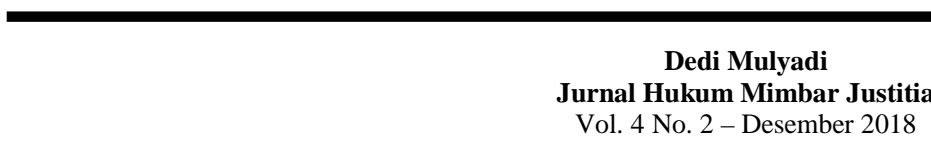

Jurnal Hukum Mimbar Justit

c. Permasalahan birokrasi penelitian khususnya pemerintah seringkali terlalu menekankan adminitrasi bukan hasil penelitiannya, jadi para peneliti banyak disibukan dengan kepentingan administrasi penelitian bukan penelitiannya.

Demikian berbagai permasalahan peran Perguruan Tinggi sesuai UndangUndang Nomor 12 tahun 2014 Tentang Pendidikan Tinggi khusus Pasal 58 Ayat (1) dalam pemilihan Kepala Daerah Tahun 2018 ini sebagai gambaran distrosi peran Perguruan Tinggi dalam implementasi demokrasi lokal.

\section{PENUTUP}

\section{A. Kesimpulan}

Peran Perguruan Tinggi dalam pelaksanaan pemilihan kepala daerah secara serentak Tahun 2018 merupakan internalisasi peran Perguruan Tinggi sesuai Undang-Undang Nomor 12 tahun 2014 Tentang Pendidikan Tinggi khusus Pasal 58 Ayat (1) yang dapat disimpulkan beberapa hal diantaranya :

1. Peran Perguruan Tinggi dalam Pelaksanaan Pilkada Tahun 2018, sesuai Undang-Undang Nomor 12 tahun 2014 Tentang Pendidikan Tinggi secara konkrit melalui kebijakan Perguruan Tinggi yang dilakukan adalah memperbanyak penelitian/study dan Diskusi tentang Pilkada, Membuat Pusat Studi Pilkada, Kebijakan Perguruan Tinggi mengenai pembukaan jurusan Pemilu di Fakultas Hukum konsentrasi jurusan Hukum Pemilu dan Fakultas Ilmu Sosial dan Ilmu Politik konsentrasi Jurusan Kepemiluan dan Kebijakan ekternal mendorong agar institusi penyelenggara pemilu tidak bersifat ad-hoc tetapi bersipat permanen dan lahirnya undangundang pemilu sebagai undangundang payung (lex generalis) yang menaungi undang-undang Penyelenggara Pemilu, Pilkada, Pileg dan Pilpers (lex specialis).

2. Permasalahan pelaksanaan peran Perguruan Tinggi dalam Pilkada Tahun 2018, berdasarkan perkembangan Peran Perguruan Tinggi ternyata tidak mudah mengingat ada berbagai permasalahan yang harus segera 
Dedi Mulyadi

Jurnal Hukum Mimbar Justitia

Vol. 4 No. 2 - Desember 2018

\begin{tabular}{|c|c|}
\hline diantaranya & Kepemiluan, \\
\hline permasalahan & terhadap \\
\hline dianataranya : Pertama, tidak ada & pembiayaan penelitian, Ketiga, \\
\hline kesamaan & permasalahan birokrasi penelitian \\
\hline fungsi Perguruan & yang sumber \\
\hline Tinggi dalam pelaksanaan Pilkada & pemerintah. \\
\hline
\end{tabular}

mengingat Pilkada merupakan

peristiwa politik, Keduan, hasil

penelitian sulit diakses oleh

pengguna (teknokrat demokrasi)

khusus mengenai topik-topik

demokrasi dan politik mutahir,

dengan demikian maka maksud

dilakukannya penelitian agar

tercipta sistem demokrasi yang

baik hasil penelitian tersebut

\section{DAFTAR ISI}

A. Buku-Buku dan Jurnal Ilmiah

Andi Saputa, Faktor-faktor

Kemenangan Calon Incumbent dalam Pilkada, dalam Jurnal Konstitusi, PK2P Universitas Muhammadiyah Yogyakarta, Vol. III, No. 1, Juni 2010, Jakarta, Mahkamah Konstitusi.

tidak dapat termanfaatkan oleh para teknokrat politik. Ketiga, Permasalahan terbatasnya pembiayaan berbagai kebijakan penelitian tentang Pemilu yang dilaksanakan oleh Perguruan Tinggi maupun oleh pihak-pihak yang terkait lainya,

Permasalahan external terdiri dari

: Pertama, Permasalahan trash atau kepercayaan dari stakeholder atas pemanfaatan hasil penelitian yang telah dilakukan oleh Perguruan Tinggi khsusnya penelitian yang berkaitan dengan

Iskandar Muda \& Muhammad Kadafi, Penerapan Konsep Hukum Pembangunan Ekonomi dalam upaya pencegahan eksploitasi pekerja alih daya, Kajian Putusan Mahkamah Konstitusi Nomor 27/PPU-IX/2011, dalam Jurnal Yudisial, Vol. 6 No. 1 April 2013, Jakarta, Komisi Yudisial.

Janedjri M. Gaffar, 2013, Politik Hukum Pemilu, Konstitusi Perss, Jakarta.

Miriam Budiarjdo, 1997, Dasar-Dasar Ilmu Politik, Cet. XIII, Gramedia Pustaka Utama, Jakarta.

Mudiarti Trisnaningsih, Peranan Hukum di Era Globalisasi, dalam 
Jurnal Ilmiah Hukum Litigasi,

Vol. 1, No. 1, April 2012,

Bandung, Fakultas Hukum

Universitas Pasundan Bandung.

Satrya Pangadaran Marpaung, Strategi

Hukum dan Demokrasi di

Indonesia dalam Pelaksanaan

Otonomi Daerah, dalam Law

Review, Vol. XII, No. 3, Maret

2013, Jakarta, Fakultas Hukum

Universitas Pelita Harapan.

Septi Nur Wijayanti, Pergeseran

Kewenangan Penyelesaian

Sengketa Pemilukada dari

Mahkamah Agung ke Mahkamah

Konstitusi, dalam Jurnal

Konstitusi, Vol. III, No. 1, Juni

2010, Jakarta, Mahkamah

Konstitusi.

Soerjono Soekanto, 2008, Pengantar

Penelitian Hukum, UI Press Raja

Grafindo, Jakarta.

Wahyu Nugroho, Politik Hukum Pasca

Putusan Mahkamah Konstitusi

atas Pelaksanaan Pemilu dan

Pemilukada di Indonesia, dalam

Jurnal Konstitusi, Vol. 13, No.3,

September 2016, Jakarta,

Mahkamah Konstitusi. 